\title{
Storage management influences greenhouse gas emissions from biosolids
}

Ramaprasad Majumder ${ }^{1}$, Stephen J. Livesley ${ }^{1}$, David Gregory ${ }^{2}$ and Stefan K Arndt* ${ }^{1,3}$

${ }^{1}$ School of Ecosystem and Forest Sciences, The University of Melbourne, 500, Yarra Boulevard, Richmond, VIC-3121, Australia;

${ }^{2}$ Technology and Marine Research, Melbourne Water, 990 Latrobe Street, Docklands, Victoria 3008, Australia.

${ }^{3}$ Terrestrial Ecosystem Research, Department of Microbiology and Ecosystem Science, University of Vienna, Althanstrasse 14, 1090 Vienna, Austria

* Corresponding author: Stefan K Arndt

Phone: (+) 61390356819

Email:sarndt@unimelb.edu.au 


\begin{abstract}
Biosolids produced by wastewater treatment plants are often stored in stockpiles and can be a significant source of greenhouse gases (GHG). Growing trees in shallow stockpiled biosolids may remove nutrients, keep the biosolids drier and offset GHG emissions through C sequestration. We directly measured methane $\left(\mathrm{CH}_{4}\right)$, carbon dioxide $\left(\mathrm{CO}_{2}\right)$ and nitrous oxide $\left(\mathrm{N}_{2} \mathrm{O}\right)$ flux from a large biosolid stockpile and two shallow stockpiles, one planted with Salix reichardtii (willow) trees, from December 2009 to January 2011. All stockpiles emitted large annual amounts of GHG ranging from $38 \mathrm{~kg} \mathrm{CO}_{2}-\mathrm{e} \mathrm{Mg}^{-1}$ dry biosolid for the large stockpile, to $65 \mathrm{~kg} \mathrm{CO}_{2}-\mathrm{e} \mathrm{Mg}^{-1}$ for the unplanted shallow stockpile, probably due to the greater surface area to volume ratio. GHG emissions were dominated by $\mathrm{N}_{2} \mathrm{O}$ and $\mathrm{CO}_{2}$ whilst $\mathrm{CH}_{4}$ emissions were negligible $(<2 \%)$ from the large stockpile and the shallow stockpiles were actually a $\mathrm{CH}_{4}$ sink.

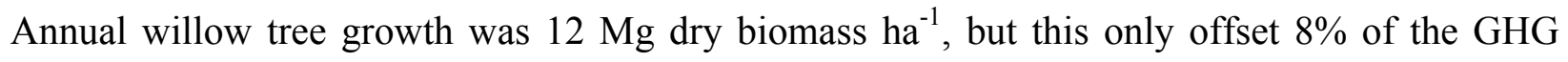
emissions from the shallow planted stockpile. Our data highlight that biosolid stockpiles are significant sources for GHG emissions but alternate management options such as shallow stockpiles or planting for biomass production will not lead to GHG emission reductions.
\end{abstract}

Keywords: Sewage sludge, respiration, biomass, carbon offset, sequestration, nitrous oxide, methane. 


\section{Introduction}

Biosolids are an end product of the sewage treatment processes and their production gradually increases every year due to sewage production from an increasing human population (Wang et al., 2008). For example, in Australia there is an approximate 3\% increase in biosolid production from wastewater treatment plants (WTPs) annually (AWA, 2013). The storage of biosolids within WTPs is necessary either temporarily, or long-term, depending upon whether an ultimate end-use is available. Desirable end uses have a low environmental impact or even an environmental and economic benefit, such as biosolid application to agricultural or production forestry systems (Pritchard et al., 2010). Biosolids are often stored in large stockpiles to minimize the use of space, but this can present a fire risk (spontaneous combustion), pollution risks (leachate and particulate) and increased GHG emission risks as they are rich in organic matter and nutrients (Fernandes et al., 2005). In fact, biosolid stockpiles can emit large amounts of greenhouse gases, especially in young stockpiles (Majumder et al., 2014).

A potential alternative end use, or long term storage option for biosolids are shallow stockpiles (e.g. $0.5 \mathrm{~m}$ deep) over larger areas and within which woody vegetation can be planted for carbon offset gains, biosolid stabilization and pollutant/nutrient removal (Laidlaw et al., 2012). In such a system, the high labile carbon and nitrogen content of the biosolid, in combination with rainfall and/or supplementary irrigation, could lead to high plant biomass production and therefore a value adding product for bioenergy or biochar production and/or carbon offset potential of related GHG emissions from the WTP. However, microbial decomposition and transformations of labile carbon and nitrogen in these stockpiles may still lead to significant production of methane $\left(\mathrm{CH}_{4}\right)$, carbon dioxide $\left(\mathrm{CO}_{2}\right)$ and nitrous oxide $\left(\mathrm{N}_{2} \mathrm{O}\right)$ under aerobic and anaerobic conditions. In WTPs, GHG emissions are generally estimated using emission factors based on 
the initial chemical properties of the wastewater or sewage sludge (Brown et al., 2010) and as such there is substantial uncertainty in these GHG emissions estimates (Bogner et al., 2008). This also relates to the storage and management of dried biosolids as direct measurements of GHG emissions from biosolids in stockpiles or other interim storage options are lacking.

The main aim of this study was to assess the magnitude of GHG emissions from three different biosolid storage and management systems: i) large stockpiles (LS), ii) unplanted shallow stockpiles (USS) and iii) planted shallow stockpiles (PSS) with willow (Salix $x$ reichardtii A.Kern).

The specific objectives of this study were to:

(1) measure the seasonal variation and magnitude of $\mathrm{CH}_{4}, \mathrm{CO}_{2}$, and $\mathrm{N}_{2} \mathrm{O}$ emissions from the three different biosolid management options;

(2) investigate the relationship between greenhouse gas fluxes and environmental variables in these storage management systems;

(3) calculate the annual $\mathrm{CH}_{4}, \mathrm{CO}_{2}$, and $\mathrm{N}_{2} \mathrm{O}$ flux balance from the three different biosolid management systems and evaluate the carbon offset potential of woody biomass growth in biosolids.

\section{Materials and method}

\subsection{Experimental set-up and site description}

The study site was located at the Western Treatment Plant (WTP) of Melbourne Water, which is located in Weribbee, $35 \mathrm{~km}$ south-west of Melbourne (37 $59^{\prime} 35^{\prime}$ 'S, $144^{\circ} 36^{\prime} 58^{\prime}$ 'E). The WTP treats wastewater of around $1.8 \mathrm{M}$ people of the western and northern suburbs of Melbourne. The 
temperate climate in the region is characterized by warm and dry summers and a relative even rainfall distribution with a maximum in spring. Historical average annual rainfall (1941-2012) is $514.4 \mathrm{~mm}$ (BOM, 2013). Currently, there are approximately 1,573,000 Mg of air-dried biosolids stockpiled at the WTP (MelbourneWater, 2010). For this study, three different management practices of biosolids storage and use were selected to quantify their GHG emissions. These were: i) large stockpiles (LS), which are commonly used ( $\sim 9.0 \mathrm{~m}$ high), ii) unplanted shallow stockpiles (USS $=0.5 \mathrm{~m}$ high) and iii) planted shallow stockpiles (PSS $=0.5 \mathrm{~m} \mathrm{high}$ ) with willow (Salix $x$ reichardtii A.Kern). The same biosolids were used for all three management options. The biosolids were collected before 1995 from the mixed sludge of a number of drying pans and were stored in biosolid stockpiles prior to the experiment commencing. The experimental area of shallow stockpiles was set up in 2005 and covered an area of approximately $7000 \mathrm{~m}^{2}$, with $2000 \mathrm{~m}^{2}$ of this being planted with willows at a stocking rate of 40,000 plants ha $^{-1}$

(or 4 plants $\mathrm{m}^{-2}$ ). The willow planting was irrigated with Class $\mathrm{C}$ waste water during the summer months, see Laidlaw et al. (2012) for more details.

\subsection{Measurement of GHG flux from three different management practices of biosolid}

The GHG flux rates of $\mathrm{CH}_{4}, \mathrm{CO}_{2}$ and $\mathrm{N}_{2} \mathrm{O}$ were measured using the closed static chamber technique (Hutchinson and Mosier, 1981) at the surface of each stockpile in the management practices LS, USS and PSS. We collected gas samples once a month from December 2009 to January 2011. On the top of each stockpile we placed eight chambers in a row about 1-2 m apart. The manual chambers consisted of non-transparent PVC pipe (diameter $25 \mathrm{~cm}$, height $24.5 \mathrm{~cm}$, volume $12.0 \mathrm{~L}$ ) and had a twist-lid incorporating a butyl-rubber septum and a rubber O-ring to form a gas tight seal. The basal area of each chamber was $0.045 \mathrm{~m}^{2}$. Manual chambers were inserted to a depth of 3-4 $\mathrm{cm}$ depth at least 15 to 30 minutes before closing the lid. After closing the chamber lids, we collected $20 \mathrm{~mL}$ headspace gas samples with a syringe at intervals of $0,4,8$ 
and 12 minutes for the large stockpile and at intervals of $0,10,20$ and 30 minutes for the shallow stockpile because of initial differences from trial gas flux measures. The gas samples were collected between 10:30 and 14:30 in pre-evacuated $12 \mathrm{~mL}$ vials (Exetainers ${ }^{\mathrm{TM}}$, Labco Pty Ltd, UK). After collecting gas samples, chamber height was measured at four positions to calculate head space volume of each chamber individually. Gas samples were analyzed using gas chromatography (GC) (Shimadzu GC17A, with $\mathrm{N}_{2}$ carrier gas) to determine $\mathrm{CH}_{4}$ concentrations using a flame ionization detector (FID) and $\mathrm{CO}_{2}$ concentrations through the addition of a Methaniser (SRI Instruments, USA) before the FID. $\mathrm{N}_{2} \mathrm{O}$ concentrations were determined using an electron capture detector (ECD) in the same GC run.

\subsection{Measurement of biosolid environmental properties}

We measured biosolid temperature (BT) with short temperature probes (Cole-Parmer, USA) at a depth of $10 \mathrm{~cm}$ at the same time as gas samples were collected. We collected biosolid samples at each measurement from the upper $0.1 \mathrm{~m}$ with a stainless steel bulk density ring near each chamber to estimate biosolid moisture content (MC), bulk density and to provide samples for $\mathrm{NO}_{3}{ }^{-}$and $\mathrm{NH}_{4}{ }^{+}$concentration analysis. We dried subsamples at $105^{\circ} \mathrm{C}$ for 48 hours and determined biosolid MC gravimetrically by weighing samples before and after drying. The $\mathrm{NO}_{3}{ }^{-}$ and $\mathrm{NH}_{4}{ }^{+}$concentration of biosolids was measured in $1 \mathrm{M} \mathrm{KCl}$ extracts $(1: 4$, biosolid: $\mathrm{KCl})$ on a Technicon $^{\mathrm{TM}}$ auto-analyser. The bulk density of biosolids was calculated dividing the mass of oven dried biosolids (g) by the volume of stainless steel ring $\left(\mathrm{cm}^{3}\right)$ (Gifford and Roderick, 2003).

\subsection{GHG flux calculation}

Curvilinear regressions best described the $\mathrm{CH}_{4}, \mathrm{CO}_{2}$ and $\mathrm{N}_{2} \mathrm{O}$ fluxes from biosolid stockpile because the gas concentration in the chamber headspace decreased gradually with time of 
chamber closure (Matson and Harriss, 1995). The following equation was used to measure the flux

$f_{o}=V^{*}\left(C_{1}-C_{0}\right)^{2} /\left[A^{*} t_{1} *\left(2 * C_{1}-C_{2}-C_{0}\right)\right] * \ln \left[\left(C_{1}-C_{0}\right) /\left(C_{2}-C_{1}\right)\right]$

where, $f_{o}$ is the flux at time $0, V$ is the chamber headspace volume (L), $A$ is the soil surface area $\left(\mathrm{m}^{2}\right), C_{0}, C_{1}$, and $C_{2}$ are the chamber headspace gas concentrations ppm(v) at different times after closure (0, 4, 8 and 12 minutes for LS and 0, 10, 20, 30 minutes for USS and PSS), respectively, and $t_{l}$ is the time between gas sampling points (Minato et al., 2013). The unit of $f_{o}$ is $\mu \mathrm{L}$ trace gas $\mathrm{m}^{-2} \min ^{-1}$.

This flux $\left(f_{o}\right)$ was then transformed to $\mu$ mol $\mathrm{CH}_{4}, \mathrm{CO}_{2}$ and $\mathrm{N}_{2} \mathrm{O} \mathrm{m} \mathrm{m}^{-2} \mathrm{~h}^{-1}$ by accounting for pressure, temperature and volume based on the ideal gas law by applying Equation 2

$F_{\mu m o l}=\frac{F \mu L P P}{R \times T}$

where $F_{\mu m o l}$ is the flux in $\mu$ mol $\mathrm{CH}_{4}, \mathrm{CO}_{2}$ and $\mathrm{N}_{2} \mathrm{O} \mathrm{m} \mathrm{m}^{-2}, F_{\mu L}$ is the flux in $\mu \mathrm{L} \mathrm{CH}_{4}, \mathrm{CO}_{2}$ and $\mathrm{N}_{2} \mathrm{O} \mathrm{m}^{-2} \mathrm{~h}^{-1}, P$ is the atmospheric pressure in $\mathrm{kPa}$ at the site depending on the altitude, $T$ is air temperature in $\mathrm{K}\left(273+{ }^{\circ} \mathrm{C}\right), R$ is the ideal gas constant $\left.=8.3144 \mathrm{~L} \mathrm{kPa} \mathrm{mol}^{-1} \mathrm{~K}^{-1}\right)$. The fluxes of $\mu$ mol $\mathrm{CH}_{4}, \mathrm{CO}_{2}$ and $\mathrm{N}_{2} \mathrm{O} \mathrm{m} \mathrm{m}^{-2} \mathrm{~h}^{-1}$ were converted to $\mu \mathrm{g} \mathrm{CH}_{4}-\mathrm{C}, \mathrm{CO}_{2}-\mathrm{C}$ and $\mathrm{N}_{2} \mathrm{O}-\mathrm{N} \mathrm{m}^{-2} \mathrm{~h}^{-1}$ depending on the molecular mass of each gas.

We measured fluxes prior to the start of the campaigns at different times of the day and we observed only small diurnal variation of flux for all GHG. We therefore decided to measure the GHG always in the same time window (see above) and estimated the daily flux of $\mathrm{CH}_{4}, \mathrm{CO}_{2}$ and 
$\mathrm{N}_{2} \mathrm{O}$, by multiplying the hourly flux $\left(\mu \mathrm{g} \mathrm{kg}^{-1} \mathrm{hr}^{-1}\right)$ of each measurement day by $24 \mathrm{hrs}$. The monthly flux of $\mathrm{CH}_{4}, \mathrm{CO}_{2}$ and $\mathrm{N}_{2} \mathrm{O}$, was calculated by multiplying the mean daily flux $\left(\mu \mathrm{g} \mathrm{kg}^{-1} \mathrm{~d}^{-}\right.$ ${ }^{1}$ ) by the days of each month. To compare the global warming potential of the different gases we converted the monthly flux to $\mathrm{kg} \mathrm{CO}_{2}$-e $\mathrm{m}^{2}$ month ${ }^{-1}$ for $\mathrm{CH}_{4}$ and $\mathrm{N}_{2} \mathrm{O}$ flux by using a global warming potential of 25 for $\mathrm{CH}_{4}$ and 298 for $\mathrm{N}_{2} \mathrm{O}$ (IPCC, 2007). Monthly $\mathrm{kg} \mathrm{CO}_{2}-\mathrm{e} \mathrm{Mg}^{-1}$ dry biosolid was estimated based on $\mathrm{m}^{2}$ monthly flux of $\mathrm{CH}_{4}, \mathrm{CO}_{2}$ and $\mathrm{N}_{2} \mathrm{O}$ of each stockpile and total dried biosolid mass (using total area, bulk density, total volume of each stockpile and moisture content).

\subsection{Carbon sequestration in woody biomass}

Woody biomass was harvested from a short rotation coppice of willow planted on $2,000 \mathrm{~m}^{2}$ of the shallow $(0.5 \mathrm{~m})$ biosolid stockpile. This willow rotation coppice consisted of 40,000 cuttings per hectare $\left(4\right.$ plants $\left.\mathrm{m}^{2}\right)$ that were harvested/coppiced once every year. After three years of annual rotation the average above-ground woody biomass production (oven dry basis) was approximately $12 \mathrm{Mg} \mathrm{ha}^{-1}$ (Laidlaw et al., 2012). It was estimated that one dry $\mathrm{Mg}$ of $0.5 \mathrm{~m}$ high biosolid stockpiled could cover $2.0243 \mathrm{~m}^{2}$. As such, one dry Mg of biosolid could support the growth of $2.4 \mathrm{~kg}$ of dry woody biomass (above ground). Carbon sequestration was estimated under the assumption that $50 \%$ of dry woody biomass is carbon (Zhang et al., 2012).

\subsection{Data analysis and presentation}

Sigma Plot 12.0 and Excel 2007 were used to analyze the data. We evaluated the significance of relationship between $\mathrm{CH}_{4}, \mathrm{CO}_{2}$ and $\mathrm{N}_{2} \mathrm{O}$ flux and moisture content, biosolid temperature, $\mathrm{NO}_{3}^{-}-$ content and $\mathrm{NH}_{4}{ }^{+}$-content using simple linear regressions. We calculated the total annual emissions ( $\mathrm{kg} \mathrm{Mg}^{-1}$ dry biosolids) of $\mathrm{CH}_{4}, \mathrm{CO}_{2}$ and $\mathrm{N}_{2} \mathrm{O}\left(\mathrm{CO}_{2}\right.$-e) by dividing the total GHG 
emissions ( $\mathrm{kg} \mathrm{Mg}^{-1}$ dry biosolids) from measured months by the number of measured months and multiplying it by 12 .

\section{Results}

\subsection{Seasonal variation in GHG emissions from biosolid storage management systems}

Of the three different biosolid storage management systems, the LS treatment had the lowest average monthly $\mathrm{N}_{2} \mathrm{O}$ emissions $\left(1.0 \mathrm{~kg} \mathrm{CO}_{2} \mathrm{e} \mathrm{Mg}^{-1}\right.$ dry biosolid) and the highest average monthly $\mathrm{CH}_{4}$ emissions ( $0.054 \mathrm{~kg} \mathrm{CO}_{2} \mathrm{e} \mathrm{Mg}^{-1}$ dry biosolid). The LS was a continuous source of $\mathrm{CH}_{4}$, with greatest emissions in September and November 2010 (Figure 1). Monthly $\mathrm{N}_{2} \mathrm{O}$ emissions from LS ranged between 0.14 and $4.4 \mathrm{~kg} \mathrm{CO}_{2}-\mathrm{e} \mathrm{Mg}^{-1}$ dry biosolid and peaked in January and November 2010. The $\mathrm{CO}_{2}$ emissions fluctuated but gradually decreased from $4.1 \mathrm{~kg}$ to $2.3 \mathrm{~kg} \mathrm{CO}_{2} \mathrm{e} \mathrm{Mg}^{-1}$ dry biosolid by the end of this study period. 


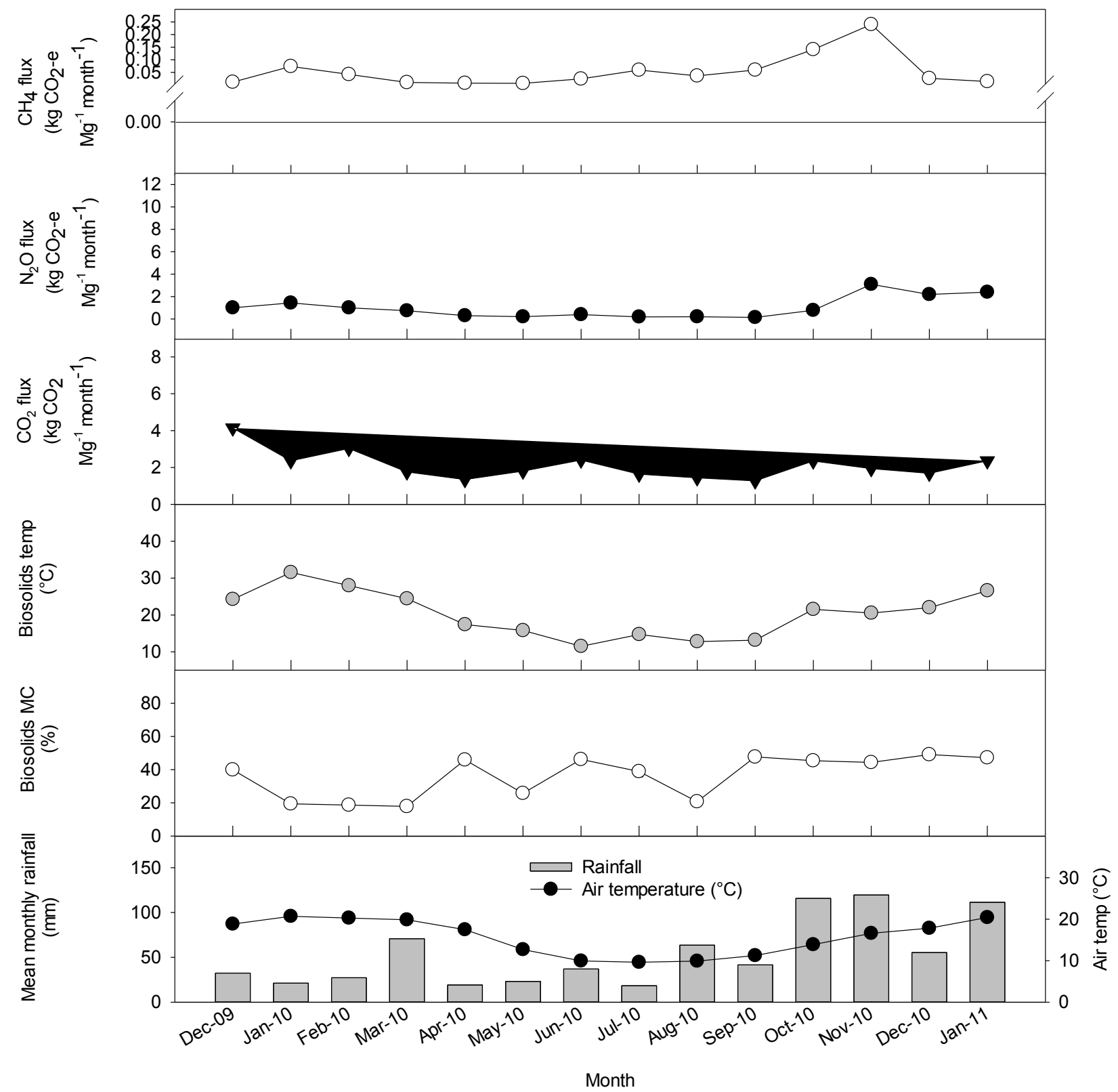

Figure 1. Fluxes of $\mathrm{CH}_{4}, \mathrm{~N}_{2} \mathrm{O}$ and $\mathrm{CO}_{2}\left(\mathrm{~kg} \mathrm{CO}_{2}\right.$-e $\mathrm{Mg}_{\text {biosolid }}{ }^{-1}$ month $\left.{ }^{-1}\right)$ from a large stockpile (LS) $(\mathrm{n}=8)$ at the Western Treatment Plant in Melbourne, Australia.

In the USS treatment, we measured zero to slightly negative $\mathrm{CH}_{4}$ flux indicating the presence of methane uptake by the biosolids and overall the stockpile was a small $\mathrm{CH}_{4} \operatorname{sink}$ (Figure 2). 


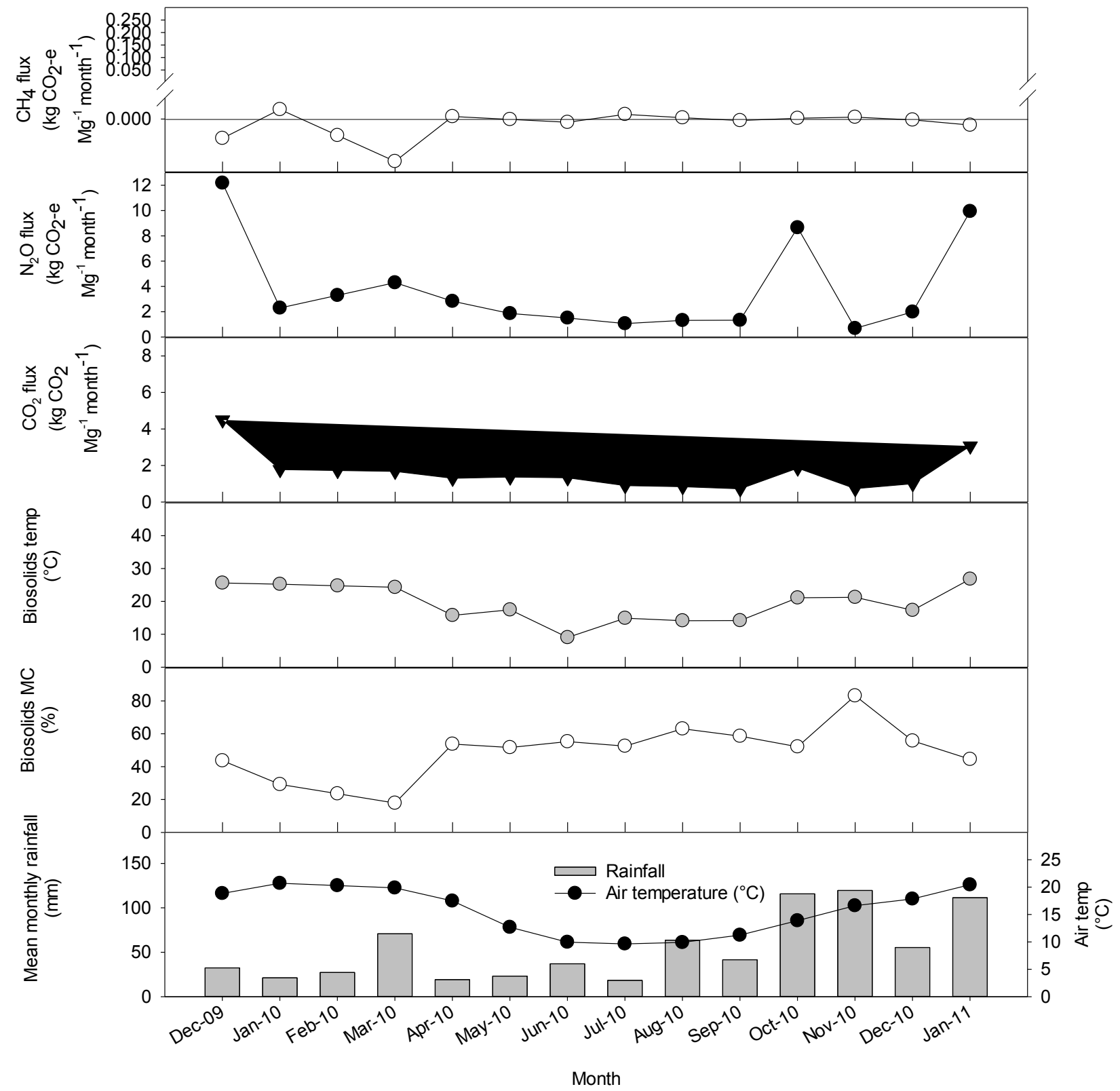

Figure 2. Fluxes of $\mathrm{CH}_{4}, \mathrm{~N}_{2} \mathrm{O}$ and $\mathrm{CO}_{2}\left(\mathrm{~kg} \mathrm{CO}_{2}\right.$-e $\mathrm{Mg}$ biosolid ${ }^{-1}$ month $\left.{ }^{-1}\right)$ from an unplanted shallow stockpile (USS) $(n=8)$ at the Western Treatment Plant in Melbourne, Australia.

The monthly measured $\mathrm{CO}_{2}$ emissions were between 0.72 and $4.5 \mathrm{~kg} \mathrm{CO}_{2} \mathrm{e} \mathrm{Mg}^{-1}$ dry biosolid. The highest emissions of $\mathrm{CO}_{2}$ were observed at beginning and end of the study, in summer months. $\mathrm{N}_{2} \mathrm{O}$ emissions from USS ranged between 0.7 and $12.1 \mathrm{~kg} \mathrm{CO}_{2} \mathrm{e} \mathrm{Mg}^{-1}$ dry biosolids 
month $^{-1}$ and were greatest in December 2009, October 2010 and January 2011, spring and summer months.

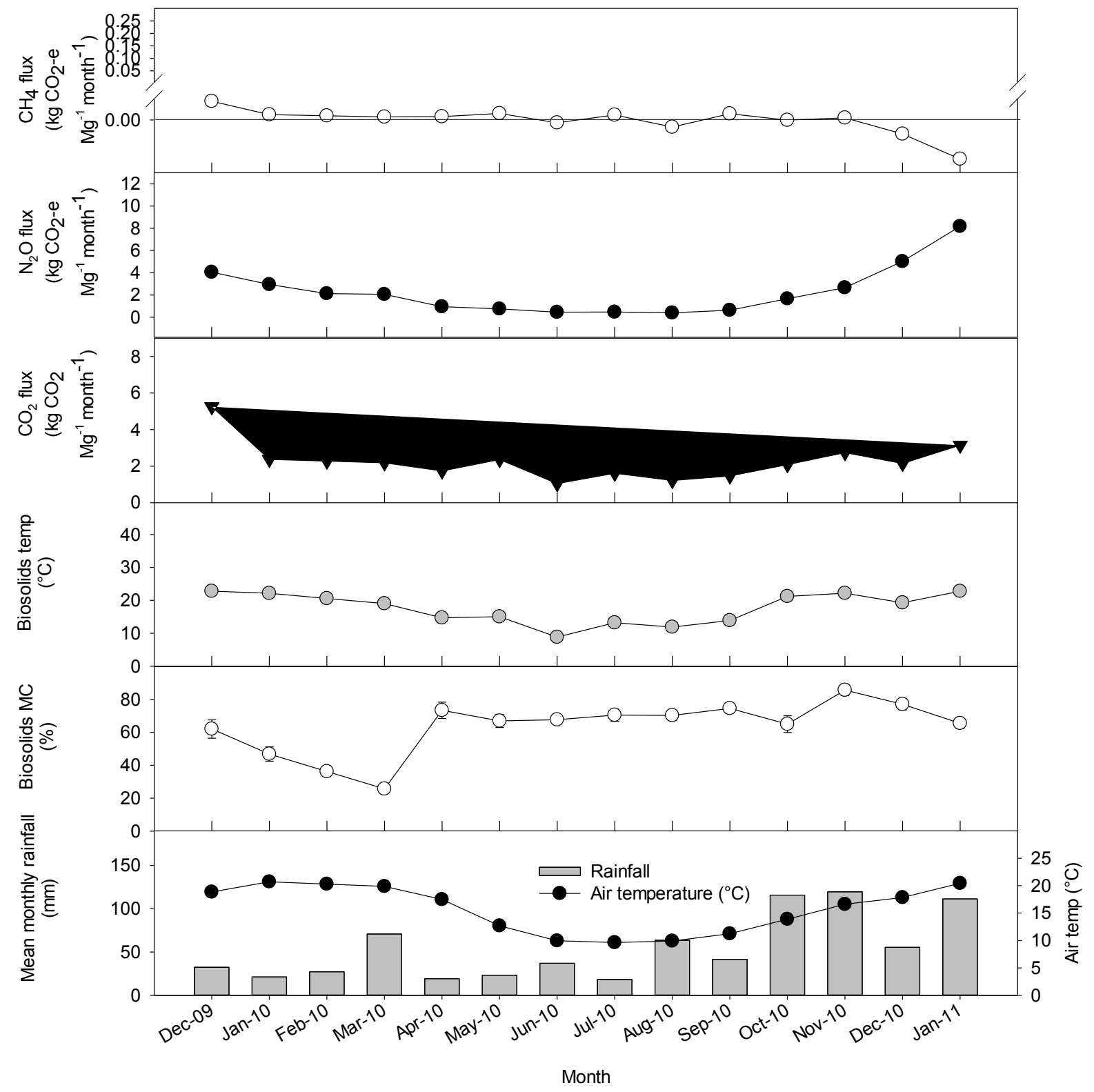

Figure 3. Fluxes of $\mathrm{CH}_{4}, \mathrm{~N}_{2} \mathrm{O}$ and $\mathrm{CO}_{2}\left(\mathrm{~kg} \mathrm{CO}_{2}-\mathrm{e} \mathrm{Mg}\right.$ biosolid $\left.{ }^{-1} \mathrm{month}^{-1}\right)$ from a planted shallow stockpile (PSS) $(n=8)$ at the Western Treatment Plant in Melbourne, Australia. 
The PSS treatment also had zero to slightly negative $\mathrm{CH}_{4}$ flux indicating the presence of methane uptake by the biosolids and was a small $\mathrm{CH}_{4}$ sink (Figure 3). Monthly measured $\mathrm{CO}_{2}$ emissions from PSS were slightly greater than from USS, ranging between 1.0 and $5.25 \mathrm{~kg} \mathrm{CO}_{2} \mathrm{e} \mathrm{Mg}^{-1}$ dry biosolid. In PSS the monthly measured $\mathrm{N}_{2} \mathrm{O}$ emissions were between 0.4 and $8.1 \mathrm{~kg} \mathrm{CO}_{2} \mathrm{e} \mathrm{Mg}^{-1}$ dry biosolid and were greatest in December and January of both measured summers.

\subsection{Seasonal variation in biosolid environmental properties}

The average moisture content of PSS and USS were between $49-63 \%$ and the average moisture content was higher in PSS as compared to USS (Figures 1, 2 and 3). The average moisture content was very low $(36 \%)$ in LS. We observed the greatest moisture content in all three stockpiles in the months of October 2010, November 2010 and January 2011 due to heavy rainfall. The average monthly rainfall of those three months was $115 \mathrm{~mm}$. The average biosolid temperature was greater in $\operatorname{LS}\left(20^{\circ} \mathrm{C}\right)$ as compared with PSS $\left(18^{\circ} \mathrm{C}\right)$ and $\operatorname{USS}\left(19^{\circ} \mathrm{C}\right)$. The highest biosolid temperature was observed in December 2009 to February 2010.

The average $\mathrm{NO}_{3}{ }^{-}-\mathrm{N}$ content was greatest in the LS $\left(190 \mathrm{mg} \mathrm{N} \mathrm{kg}^{-1}\right)$, more than twice than in USS (72 $\left.\mathrm{mg} \mathrm{N} \mathrm{kg}^{-1}\right)$ and three times greater than in PSS (53 $\mathrm{mg} \mathrm{N} \mathrm{kg}^{-1}$ ) (Figure 4). We observed less disparity and variation in the average $\mathrm{NH}_{4}{ }^{+}-\mathrm{N}$ contents, which were greater in USS $(9 \mathrm{mg} \mathrm{N}$ $\left.\mathrm{kg}^{-1}\right)$ than PSS $\left(5 \mathrm{mg} \mathrm{N} \mathrm{kg}^{-1}\right)$ and the LS $\left(1 \mathrm{mg} \mathrm{N} \mathrm{kg}^{-1}\right)$. 


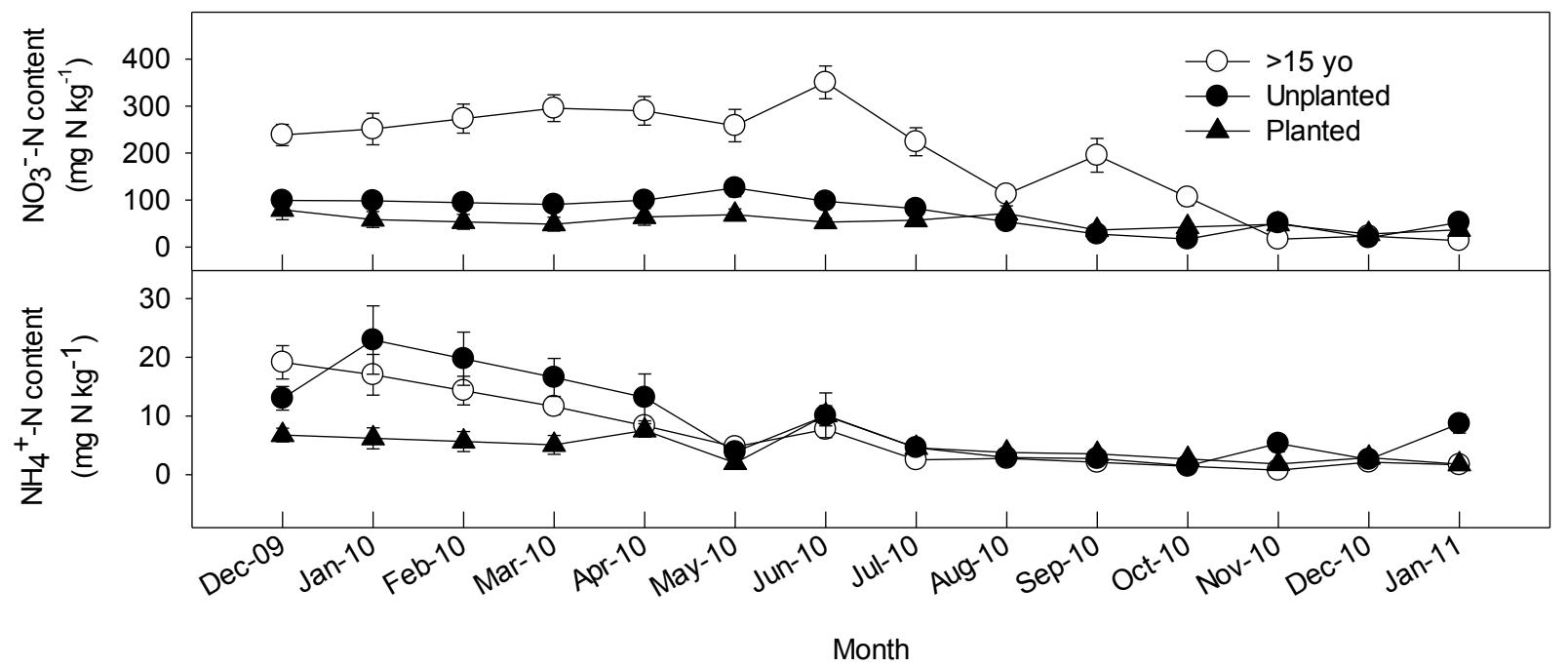

Figure 4. Monthly $\mathrm{NO}_{3}{ }^{-}$and $\mathrm{NH}_{4}{ }^{+}$concentration $\left(\mathrm{mg} \mathrm{N} \mathrm{kg}{ }^{-1}\right.$ ) from the large stockpile (LS), unplanted shallow stockpile (USS) and planted shallow stockpile (PSS) (SE, n=8) at the Western Treatment Plant in Melbourne, Australia.

\subsection{Relationships between biosolid environmental variables and GHG flux}

We observed only weak relationships between MC and GHG flux in all biosolid stockpile treatments. A significant $(\mathrm{p} \leq 0.05)$ but weak correlation existed between $\mathrm{MC}$ and $\mathrm{CH}_{4}$ flux for USS (Table 1). But we did not detect any significant relationship between $\mathrm{MC}$ and $\mathrm{CH}_{4}$ flux in the LS or PSS treatments. We also did not observe any significant relationship between MC and either $\mathrm{N}_{2} \mathrm{O}$ or $\mathrm{CO}_{2}$ emissions from either of the three treatments. 
Table 1. The relationship and level of significance between fluxes of methane $\left(\mathrm{CH}_{4}\right)$, nitrous oxide $\left(\mathrm{N}_{2} \mathrm{O}\right)$ and carbon dioxide $\left(\mathrm{CO}_{2}\right)$ and biosolid moisture content $(\mathrm{MC})$, biosolid temperature (BT), $\mathrm{NO}_{3}{ }^{-}-\mathrm{N}$ concentration and $\mathrm{NH}_{4}{ }^{+}-\mathrm{N}$ concentration at $10 \mathrm{~cm}$ depth in large stockpile (LS), unplanted shallow stockpile (USS) and planted shallow stockpile (PSS) management system at the Western Treatment Plant in Melbourne, Australia.

\begin{tabular}{|c|c|c|c|c|c|c|}
\hline & \multicolumn{6}{|c|}{ GHG flux (kg CO 2 -e dry Mg biosolid ${ }^{-1}$ month $^{-1}$ ) } \\
\hline Stockpiles & \multicolumn{2}{|l|}{$\mathrm{CH}_{4}$} & \multicolumn{2}{|l|}{$\mathrm{N}_{2} \mathrm{O}$} & \multicolumn{2}{|l|}{$\mathrm{CO}_{2}$} \\
\hline $\mathrm{MC}$ at $10 \mathrm{~cm}(\%)$ & $\mathrm{R}^{2}$ & $p$ & $\mathrm{R}^{2}$ & $p$ & $\mathrm{R}^{2}$ & $p$ \\
\hline LS & 0.04 & ns & 0.05 & ns & 0.07 & ns \\
\hline USS & 0.36 & $<0.05$ & 0.09 & ns & 0.09 & ns \\
\hline PSS & 0.02 & ns & 0.007 & ns & 0.01 & ns \\
\hline \multicolumn{7}{|l|}{ BT at $10 \mathrm{~cm}\left({ }^{\circ} \mathrm{C}\right)$} \\
\hline LS & 0.003 & ns & 0.31 & $<0.05$ & 0.47 & $<0.05$ \\
\hline USS & 0.17 & ns & 0.38 & $<0.05$ & 0.41 & $<0.05$ \\
\hline PSS & 0.01 & ns & 0.38 & $<0.05$ & 0.53 & $<0.05$ \\
\hline \multicolumn{7}{|c|}{$\mathrm{NO}_{3}{ }^{-}-\mathrm{N}$ concentration $\left(\mathrm{mg} \mathrm{N} \mathrm{kg}^{1}\right)$} \\
\hline LS & 0.23 & ns & 0.49 & $<0.05$ & 0.04 & ns \\
\hline USS & 0.05 & ns & 0.004 & ns & 0.06 & ns \\
\hline PSS & 0.32 & $<0.05$ & 0.14 & ns & 0.18 & ns \\
\hline \multicolumn{7}{|c|}{$\mathrm{NH}_{4}{ }^{+}-\mathrm{N}$ concentration $\left(\mathrm{mg} \mathrm{N} \mathrm{kg}{ }^{-1}\right)$} \\
\hline LS & 0.12 & ns & 0.02 & ns & 0.61 & $<0.05$ \\
\hline USS & 0.14 & ns & 0.02 & ns & 0.13 & ns \\
\hline PSS & 0.15 & ns & 0.11 & $\mathrm{~ns}$ & 0.24 & ns \\
\hline
\end{tabular}

We observed only weak relationships between GHG flux and BT in all stockpile treatments. There were significant $(\mathrm{p} \leq 0.05)$ correlations between $\mathrm{N}_{2} \mathrm{O}$ emissions and $\mathrm{BT}$, and $\mathrm{CO}_{2}$ emissions and BT in the LS, USS and PSS biosolid treatments (Table 1). We detected no significant relationships between $\mathrm{CH}_{4}$ flux and BT in any of the stockpiles.

There was no strong correlation between $\mathrm{NO}_{3}{ }^{-} \mathrm{N}$ or $\mathrm{NH}_{4}{ }^{+}-\mathrm{N}$ contents and GHG flux. However, there was a weak correlation between $\mathrm{NO}_{3}{ }^{-} \mathrm{N}$ and $\mathrm{CH}_{4}$ flux for PSS and a weak correlation between $\mathrm{NO}_{3}{ }^{-}-\mathrm{N}$ and $\mathrm{N}_{2} \mathrm{O}$ emissions from LS. 
There were no relationships between $\mathrm{NH}_{4}{ }^{+}-\mathrm{N}$ and flux of $\mathrm{CH}_{4}$ or $\mathrm{N}_{2} \mathrm{O}$ from either LS, USS and PSS. However, there was a good correlation between $\mathrm{NH}_{4}{ }^{+}-\mathrm{N}$ and $\mathrm{CO}_{2}$ emissions from the LS.

\section{4 Annual GHG balance for three biosolid storage and management systems}

Overall, annual GHG ( $\mathrm{CO}_{2}$-e) emissions were greatest from USS (65.2 $\mathrm{kg} \mathrm{Mg}^{-1}$ dry biosolid), followed by PSS (54.8 $\mathrm{kg} \mathrm{Mg}^{-1}$ ) and were least from the LS (38.0 $\mathrm{kg} \mathrm{Mg}^{-1}$ ) (Table 2). This values was reversed when annual GHG emissions $\left(\mathrm{CO}_{2}-\mathrm{e}\right)$ were calculated on an area (hectare) basis as they were greatest in LS (393 $\mathrm{Mg} \mathrm{CO}_{2}-\mathrm{e} \mathrm{ha}^{-1} \mathrm{yr}^{-1}$ ) followed by USS (195.3 $\mathrm{Mg} \mathrm{CO}_{2}$-e $\mathrm{ha}^{-1} \mathrm{yr}^{-1}$ ) and PSS (158.9 $\left.\mathrm{Mg} \mathrm{CO}_{2}-\mathrm{e} \mathrm{ha}^{-1} \mathrm{yr}^{-1}\right)$.

Table 2. Estimated annual GHG emissions on a mass basis $\left(\mathrm{kg} \mathrm{CO}_{2}\right.$-e dry $\left.\mathrm{Mg}^{-1} \mathrm{yr}^{-1}\right)$ and area basis ( $\left.\mathrm{Mg} \mathrm{CO}_{2}-\mathrm{e} \mathrm{ha}^{-1} \mathrm{yr}^{-1}\right)$ from the large stockpile (LS), unplanted shallow stockpile (USS) and planted shallow stockpile (PSS) and the associated C-e offset by the willow plantation (kg dry $\mathrm{Mg}^{-1}$ of biosolid or $\mathrm{kg} \mathrm{ha}^{-1} \mathrm{yr}^{-1}$ ) at the Western Treatment Plant in Melbourne, Australia.

\begin{tabular}{|c|c|c|c|c|c|}
\hline \multirow[t]{2}{*}{ Stockpiles } & \multicolumn{4}{|c|}{$\begin{array}{l}\text { Annual GHG emissions } \\
\mathrm{kg}\left(\mathrm{CO}_{2}-\mathrm{e}\right) \text { dry } \mathrm{Mg}^{-1} \text { of biosolid }\end{array}$} & \multirow[t]{2}{*}{$\begin{array}{l}\text { Plant biomass } \\
\left(\mathrm{kg} \mathrm{Mg}^{-1} \text { dry biosolid } \mathrm{yr}^{-1}\right)\end{array}$} \\
\hline & $\mathrm{CH}_{4}$ & $\mathrm{~N}_{2} \mathrm{O}$ & $\mathrm{CO}_{2}$ & Total & \\
\hline LS & 0.64 & 12.1 & 25.3 & 38.0 & - \\
\hline USS & -0.006 & 45.6 & 19.5 & 65.2 & - \\
\hline \multirow[t]{3}{*}{ PSS } & -0.001 & 27.7 & 27.1 & 54.8 & 2.4 \\
\hline & \multicolumn{4}{|c|}{$\begin{array}{l}\text { Annual GHG emissions } \\
\left(\mathrm{Mg} \mathrm{CO}_{2}-\mathrm{e}^{-{ }^{-1}} \mathrm{yr}^{-1}\right)\end{array}$} & $\begin{array}{l}\text { Plant biomass } \\
\left(\mathrm{Mg} \mathrm{ha}^{-1} \mathrm{yr}^{-1}\right)\end{array}$ \\
\hline & $\mathrm{CH}_{4}$ & $\mathrm{~N}_{2} \mathrm{O}$ & $\mathrm{CO}_{2}$ & Total & \\
\hline LS & 6.6 & 124.8 & 261.7 & 393.1 & - \\
\hline USS & -0.02 & 136.8 & 58.5 & 195.3 & - \\
\hline PSS & -0.002 & 80.4 & 78.5 & 158.9 & 12 \\
\hline
\end{tabular}

The GHG balance of the LS was dominated by $\mathrm{CO}_{2}$ emissions (67\%), whilst $\mathrm{N}_{2} \mathrm{O}$ contributed to a smaller degree $(32 \%)$ and $\mathrm{CH}_{4}$ emissions were less than $2 \%$. Conversely, in USS, $\mathrm{N}_{2} \mathrm{O}$ 
emissions accounted for $70 \%$ of the annual GHG emissions, whilst $\mathrm{CO}_{2}$ contributed the remainder of emissions, and $\mathrm{CH}_{4}$ was actually taken up by this stockpile. In the PSS, $\mathrm{CO}_{2}$ and $\mathrm{N}_{2} \mathrm{O}$ contributed almost equal amounts to the GHG balance and this stockpile was also a small $\mathrm{CH}_{4}$ sink (Table 2). The PSS annually produced $2.4 \mathrm{~kg}$ tree dry biomass $\mathrm{Mg}^{-1}$ dry biosolid (or 12 $\mathrm{Mg}$ biomass per hectare), which equates to a $\mathrm{C}$ sequestration of $4.4 \mathrm{~kg} \mathrm{CO}_{2}-\mathrm{e} \mathrm{Mg}^{-1}$. This offsets approximately $8 \%$ of the $54.8 \mathrm{~kg} \mathrm{CO}_{2}$-e $\mathrm{Mg}^{-1}$ of $\mathrm{GHG}$ emissions that were emitted by this stockpile annually.

\section{Discussion}

\section{1 $\mathrm{CH}_{4}, \mathrm{CO}_{2}$, and $\mathrm{N}_{2} \mathrm{O}$ emissions from the three different biosolid management systems}

Our direct measurements of GHG emissions from different biosolid stockpile options revealed that biosolids are a significant source for GHG. The different storage options changed the rate and contribution of the different GHG species but biosolids were a strong GHG source regardless of whether they were stored conventionally, in shallow stockpiles either unplanted or planted with trees. The main GHGs that contributed to the overall emissions balance were $\mathrm{N}_{2} \mathrm{O}$ and $\mathrm{CO}_{2}$, whilst emissions of $\mathrm{CH}_{4}$ were either very low (LS) or negative creating a weak $\mathrm{CH}_{4}$ sink (USS and PSS).

GHG emissions from any stockpile of organic material will largely depend on the characteristics of organic materials, the height and shape of the pile and environmental factors like moisture content and temperature (Boldrin et al., 2009; Peigne and Girardin, 2004). Anaerobic conditions inside a large conventional biosolid stockpile can lead to the production of $\mathrm{CH}_{4}$, when labile organic material is decomposed by methanogenic bacteria. Hence, this can explain the $\mathrm{CH}_{4}$ emissions from the LS. However, given that $\mathrm{CO}_{2}$ emissions from the LS were almost 40 fold 
greater than $\mathrm{CH}_{4}$ emissions it is likely that anaerobic conditions in the stockpile are either not prevalent or that large proportions of the produced $\mathrm{CH}_{4}$ are oxidized before they reach the surface. Consequently, the bulk of the labile organic material in the LS was oxidised and reaches the atmosphere as $\mathrm{CO}_{2}$. Both shallow biosolid stockpiles showed small $\mathrm{CH}_{4}$ uptake rates. Methanotophic bacteria can consume $\mathrm{CH}_{4}$ as an energy source under aerobic conditions (Hanson and Hanson, 1996). The shallow application of biosolid probably prevented anaerobic conditions developing, especially as biosolids generally have a low bulk density of 750-850 $\mathrm{kg} \mathrm{m}^{-3}$. Methane uptake is frequently observed in drier upland soils and represents the largest terrestrial sink for $\mathrm{CH}_{4}$ (Dalal and Allen, 2008). The $\mathrm{CH}_{4}$ uptake rate observed in both shallow biosolid treatments is similar to the uptake rates observed in urban (Livesley et al., 2010), agricultural (Livesley et al., 2008), savanna (Livesley et al., 2011) or forest ecosystems (Fest et al., 2009). Hence, shallow stockpiling leads to a decrease in $\mathrm{CH}_{4}$ emission to the atmosphere by decreasing $\mathrm{CH}_{4}$ production and/or increasing $\mathrm{CH}_{4}$ oxidation, but this effect is small in the context of the overall GHG balance.

Nitrous oxide emissions are recognized as being strongly regulated by the availability of organic carbon and nitrogen substrates, and environmental factors, such as temperature and moisture (Peigne and Girardin, 2004). Nitrous oxide emissions were generally very high from all biosolid stockpile options and much greater than generally observed in natural systems, agriculture or even following biosolid applications as soil amendments (Dalal and Allen, 2008; Livesley et al., 2009; Thangarajan et al., 2013). In arable cropped soils $\mathrm{N}_{2} \mathrm{O}$ emissions vary from $<1 \mathrm{~kg} \mathrm{~N}_{2} \mathrm{O}-\mathrm{N}$ $\mathrm{ha}^{-1} \mathrm{yr}^{-1}$ from leys and extensive pastures to $>10 \mathrm{~kg} \mathrm{~N}_{2} \mathrm{O}-\mathrm{N} \mathrm{ha}^{-1} \mathrm{yr}^{-1}$ from sugarcane crops and intensively managed dairy pastures (Dalal et al., 2003). In comparison, the biosolid stockpiles had emission rates that were 20 times greater than the highest arable soil emission (Table 2), so 
they represent a large $\mathrm{N}_{2} \mathrm{O}$ source. In agricultural soils $\mathrm{N}_{2} \mathrm{O}$ emissions are often directly related to $\mathrm{N}$-fertilizer or organic amendments and microbial transformation through nitrification or denitrification. Biosolids contain large amounts of labile nitrogen (Roy et al., 2011) and mineralization of this source leads to large concentration of $\mathrm{NO}_{3}{ }^{-}-\mathrm{N}$ and $\mathrm{NH}_{4}{ }^{+}-\mathrm{N}$. In our study, the biosolid $\mathrm{NO}_{3}^{-}-\mathrm{N}$ concentration was generally $>200 \mathrm{mg} \mathrm{N} \mathrm{kg}{ }^{-1}$, which is five to ten fold greater than that commonly reported in fertilized agricultural soils. Nitrate concentrations were considerably greater in the LS than in both USS and PSS. Available $\mathrm{NO}_{3}{ }^{-} \mathrm{N}$ is a substrate for denitrification, which might suggest that denitrification is not a dominant process in the LS stockpile, as this inorganic $\mathrm{N}$ substrate had accumulated without further denitrifier transformation. Biosolid $\mathrm{NH}_{4}^{+}-\mathrm{N}$ content was greatest in USS, and this shallow stockpile also had greater $\mathrm{NO}_{3}{ }^{-}-\mathrm{N}$ content than its planted counterpart. So despite being irrigated in summer by class $\mathrm{C}$ wastewater, the $\mathrm{N}$ uptake by willow trees appears to have reduced inorganic $\mathrm{N}$ contents in the biosolids and thereby potentially reduced $\mathrm{N}_{2} \mathrm{O}$ emissions. This was in fact apparent, as PSS had less overall $\mathrm{N}_{2} \mathrm{O}$ emissions than USS.

The other factors that influence nitrification and denitrification processes are moisture content and temperature. Moisture content increases nitrification rates and thereby nitrification derived $\mathrm{N}_{2} \mathrm{O}$ emissions up to a maximum water holding capacity $(\% \mathrm{WHC})$ of approximately $60 \%$, whereas $\mathrm{N}_{2} \mathrm{O}$ production through denitrification generally is promoted at greater moisture contents (Dalal et al., 2003). The PSS was generally wetter than the USS, and yet had smaller $\mathrm{N}_{2} \mathrm{O}$ emissions despite this and the available $\mathrm{NO}_{3}{ }^{-}-\mathrm{N}$ and $\mathrm{NH}_{4}{ }^{+}-\mathrm{N}$ contents, which again might suggest that denitrification was not the dominant $\mathrm{N}_{2} \mathrm{O}$ production process in the shallow stockpiles and that nitrification processes played an important role in $\mathrm{N}_{2} \mathrm{O}$ production. In compost stockpiles oxygen and moisture contents influenced both nitrification and denitrification 
as moisture content and the supply of oxygen enhance microbial activities that produce $\mathrm{N}_{2} \mathrm{O}$ (Peigne and Girardin, 2004). However, the exact mechanisms behind the $\mathrm{N}_{2} \mathrm{O}$ emissions measured in our different biosolid stockpiles are not clear.

Greater $\mathrm{N}_{2} \mathrm{O}$ emissions were observed from both shallow stockpiles as compared to the LS. This could be due to the lower depth of the shallow biosolid stockpiles, and therefore the greater surface area to volume of biosolid. A greater surface area to volume ratio would mean that a greater proportion of biosolid experiences the variations in temperature and moisture and has less distance for diffusion of GHGs from point of production to the atmosphere and for diffusion of oxygen into the stockpile (for aerobic processes such as nitrification). As such, the greater depth of stockpiles will generally slow the rate of organic matter decomposition and other microbially mediated processes. In cattle manure stockpiles microorganisms start to decompose (oxidize) organic matter from the top of the stockpile and then move downwards when fresh, labile substrate became less available at the surface (Hao et al., 2001). The greater $\mathrm{N}_{2} \mathrm{O}$ emission rates from USS and PSS also support the proposal that microbially mediated processes may occur at faster rates in shallower stockpiles.

Carbon dioxide was the dominant form of carbon emission to the atmosphere in all biosolid stockpiles and the annual emission rates were comparable between the stockpiles, although USS had slightly lower $\mathrm{CO}_{2}$ emissions compared to the others. Compared to soil based ecosystems the $\mathrm{CO}_{2}$ emissions from the biosolid stockpiles were very high. Grasslands have an annual respiration rate around $16 \mathrm{Mg} \mathrm{CO}_{2} \mathrm{ha}^{-1}$, croplands are slightly higher at $20 \mathrm{Mg} \mathrm{CO}_{2} \mathrm{ha}^{-1}$, and the greatest soil respiration rates are commonly observed in tropical forests with around $46 \mathrm{Mg} \mathrm{CO}_{2}$ $\mathrm{ha}^{-1}$ (Raich and Schlesinger, 1992). Hence, $\mathrm{CO}_{2}$ efflux rates observed here are much greater with $58-78 \mathrm{Mg} \mathrm{CO}_{2} \mathrm{ha}^{-1}$ in the shallow stockpiles and $262 \mathrm{Mg} \mathrm{CO}_{2} \mathrm{ha}^{-1}$ in the large stockpile (Table 
2), which is likely attributed to the large reservoir of labile carbon in the biosolids. The difference in $\mathrm{CO}_{2}$ emissions between the LS and USS can be explained by the differences in current biosolid properties, moisture, temperature but perhaps most importantly differences in the availability of labile carbon. If the shallow stockpiles experience greater rates of microbial decomposition, then they are likely to reduce their stores of labile or more-available carbon more rapidly. Conversely, the large differences in $\mathrm{CO}_{2}$ emissions between USS and PSS cannot be explained by differences according to stockpile size and surface area to volume ratio - as they are similar. It is more likely that these differences in $\mathrm{CO}_{2}$ emissions are due mainly to the presence of willow root respiration, willow rhizosphere respiration and possibly the influence of irrigation with Class $\mathrm{C}$ water in summer months.

\subsection{Relationship between GHG flux and environmental parameters of biosolid stockpiles}

Environmental parameters of biosolid stockpiles that exhibit a strong relationship to the measured GHG fluxes could provide a simpler and cheaper opportunity to monitor change and therefore predict or indicate GHG emissions. Strong relationships between moisture content and/or temperature and GHG fluxes are often observed in many native and agricultural ecosystems as many microbial processes are strongly influenced by these parameters (e.g. Fest et al., 2009; Livesley et al., 2009). However, in our study we did not observe strong relationships between biosolid MC and GHG flux. In the LS, GHG are probably produced much deeper in the profile under aerobic or anaerobic conditions and then diffuse upwards to the surface and the atmosphere (Majumder et al., 2014). This would suggest that monitoring of environmental properties deeper in a stockpile may be required. Such monitoring at depth would also be beneficial for detecting high temperatures that may lead to combustions and stockpile burns, which once initiated are difficult to stop. 
However, we did observe a weak relationship between biosolid temperatures at a $10 \mathrm{~cm}$ depth and both $\mathrm{N}_{2} \mathrm{O}$ and $\mathrm{CO}_{2}$ flux in the LS, USS and PSS. This suggests a weak seasonal pattern, in that microbial processes, and associated $\mathrm{N}_{2} \mathrm{O}$ and $\mathrm{CO}_{2}$ emissions, are greater in warm summer months and lesser in cooler winter months, which is consistent with first principles.

We did not observe any strong relationship between $\mathrm{NO}_{3}{ }^{-} \mathrm{N}$ or $\mathrm{NH}_{4}{ }^{+}-\mathrm{N}$ concentrations and $\mathrm{N}_{2} \mathrm{O}$ flux. This could be due to only sampling the upper $10 \mathrm{~cm}$ which may not represent the profile position of greatest nitrification / denitrification activity and therefore $\mathrm{N}_{2} \mathrm{O}$ production. Similarly, it could also be due to the fact that inorganic $\mathrm{N}$ pool size measures are not an adequate indication of turnover or transformation rates through those pools. For example, a large $\mathrm{NO}_{3}{ }^{-} \mathrm{N}$ pool may turnover only once a week, whereas a small $\mathrm{NO}_{3}{ }^{-}-\mathrm{N}$ pool may be turning over several times a day, thereby leading to greater overall $\mathrm{N}_{2} \mathrm{O}$ emissions (Murphy et al., 2003). Unless other environmental properties show greater correlation with GHG gas exchange from biosolid stockpiles it appears that direct GHG flux measures are required if accurate estimates of GHG emissions are to be produced.

\subsection{Calculated annual GHG emissions from biosolid stockpile treatments and carbon offset from the shallow surface biosolid stockpile}

The overall annual GHG balance of PSS was slightly less than that for USS. Both shallow stockpiles had a similar weak $\mathrm{CH}_{4}$ uptake, but the planted shallow stockpile had a much lower $\mathrm{N}_{2} \mathrm{O}$ emission, probably driven by a greater $\mathrm{N}$-uptake by willow roots, and a slightly greater $\mathrm{CO}_{2}$ emission, likely caused by the autotrophic respiration of willow roots. We estimated that the willow trees planted in PSS produced about $12 \mathrm{Mg}$ of dry above-ground biomass per hectare, which equates to a $\mathrm{CO}_{2}$ offset of $4.4 \mathrm{~kg} \mathrm{CO}_{2} \mathrm{Mg}^{-1}$ dry biosolid. This estimate is comparable with 
other studies; Elowson (1999) studied different varieties of willow (Salix viminalis) and measured annual above ground biomass between 10 and $12 \mathrm{Mg}$ per hectare, and noted that yield was dependent on factors such as planting density (Bullard et al., 2002) nutrient and water supply (Weih and Nordh, 2002). The total annual GHG emissions from the PSS were $58.4 \mathrm{~kg}$ $\mathrm{CO}-\mathrm{e} \mathrm{Mg}^{-1}$ dry biosolid. This means the $4.4 \mathrm{~kg} \mathrm{CO}_{2} \mathrm{Mg}^{-1}$ dry biosolid that were sequestered by aboveground willow biomass offset only around $8 \%$ of the net GHG emissions from shallow biosolid stockpile. Consequently, the carbon sequestration potential of biosolid plantation systems seems minimal. This is not because trees did not grow well in biosolids, $12 \mathrm{Mg} \mathrm{ha}^{-1} \mathrm{yr}^{-1}$ is a very high rate of biomass accumulation, but because of the very high $\mathrm{N}_{2} \mathrm{O}$ emissions and sizable $\mathrm{CO}_{2}$ emissions that were caused by decomposition of the labile carbon and nitrogen in the biosolid stockpiles.

The direct measurement of GHG emissions from different biosolid stockpile options revealed that all biosolid stockpiles are a large source for GHGs. Labile forms of carbon and nitrogen are readily mineralized and produce much greater GHG emissions as compared to soil based systems. Some of this nitrogen is emitted in the form of $\mathrm{N}_{2} \mathrm{O}$ and much of the labile carbon is emitted as $\mathrm{CO}_{2}$, whilst $\mathrm{CH}_{4}$ is a minor emission or is even taken up by shallow biosolids. Our study also revealed that spreading biosolid in shallower stockpiles does not decrease GHG emissions. On the contrary, a greater proportion of biosolids is exposed to the elements or diffusion pathways are shorter and consequently biosolids in shallow stockpiles had greater $\mathrm{N}_{2} \mathrm{O}$ and similar $\mathrm{CO}_{2}$ emissions. Planting trees in shallow biosolids lead to smaller GHG emissions compared to unplanted shallow biosolid stockpiles; but because of the greater exposure of biosolids in the shallower application they still had greater emissions than conventional 
stockpiles. The carbon sequestration by trees offset only $8 \%$ of the total emissions despite a sizable tree biomass accumulation, again confirming the large magnitude of GHG emissions.

These results indicate that the management options in regard to reducing GHG emissions from biosolid stockpiles are very limited. Conventional stockpiles overall emitted less GHG compared to shallow stockpiles but they still had a huge emission footprint. The water industry needs to account for GHG emissions from biosolid storage and end-use in preparation for any national carbon-trading scheme. However, our data also indicate that alternate end-uses for biosolids, such as applications as soil amendments or substrates for bioenergy production should be explored as stockpiling of biosolids produces large GHG emissions.

\section{Acknowledgements}

The authors thank Kevin Gillett and Scott Laidlaw for help during the field based measurements. The study was supported by funding from the Australian Research Council (ARC) grants LE0882936, LP0883573 and DP120101735 and the Melbourne Water Corporation.

\section{References}

Australian Water Association, 2014. Biosolids production and end use in Australia. http://www.biosolids.com.au/bs-australia.php (accessed 02.12.2014)

Bogner, J., Pipatti, R., Hashimoto, S., Diaz, C., Mareckova, K., Diaz, L., Kjeldsen, P., Monni, S., Faaij, A., Gao, Q.X., Zhang, T., Ahmed, M.A., Sutamihardja, R.T.M., Gregory, R., 2008. Mitigation of global greenhouse gas emissions from waste: conclusions and strategies from the Intergovernmental Panel on Climate Change (IPCC) Fourth Assessment Report. Working Group III (Mitigation). Waste Manage. Res. 26, 11-32. 
Boldrin, A., Andersen, J.K., Moller, J., Christensen, T.H., Favoino, E., 2009. Composting and compost utilization: accounting of greenhouse gases and global warming contributions. Waste Manage. Res. 27, 800-812.

BOM, 2013. Werribee weather forecast, Bureau of Meteorology, Melbourne. http://www.bom.gov.au/vic/ (accessed 02.12.2014)

Brown, S., Beecher, N., Carpenter, A., 2010. Calculator tool for determining greenhouse gas emissions for biosolids processing and end use. Environ. Sci. Technol. 44, 9509-9515.

Bullard, M.J., Mustill, S.J., McMillan, S.D., Nixon, P.M.I., Carver, P., Britt, C.P., 2002. Yield improvements through modification of planting density and harvest frequency in short rotation coppice Salix spp. - 1. Yield response in two morphologically diverse varieties. Biomass Bioenerg. 22, 15-25.

Dalal, R.C., Allen, D.E., 2008. Greenhouse gas fluxes from natural ecosystems. Aust. J. Bot. 56, 369-407.

Dalal, R.C., Wang, W.J., Robertson, G.P., Parton, W.J., 2003. Nitrous oxide emission from Australian agricultural lands and mitigation options: a review. Aust. J. Soil Res. 41, 165-195.

Elowson, S., 1999. Willow as a vegetation filter for cleaning of polluted drainage water from agricultural land. Biomass Bioenerg. 16, 281-290.

Fernandes, S.A.P., Bettiol, W., Cerri, C.C., Camargo, P., 2005. Sewage sludge effects on gas fluxes at the soil-atmosphere interface, on soil delta C-13 and on total soil carbon and nitrogen. Geoderma 125, 49-57.

Fest, B.J., Livesley, S.J., Drosler, M., van Gorsel, E., Arndt, S.K., 2009. Soil-atmosphere greenhouse gas exchange in a cool, temperate Eucalyptus delegatensis forest in south-eastern Australia. Agric. For. Meteorol. 149, 393-406.

Gifford, R.M., Roderick, M.L., 2003. Soil carbon stocks and bulk density: spatial or cumulative mass coordinates as a basis of expression? Glob. Change Biol. 9, 1507-1514. 
Hanson, R.S., Hanson, T.E., 1996. Methanotrophic bacteria. Microbiol. Rev. 60, 439-471.

Hao, X.Y., Chang, C., Larney, F.J., Travis, G.R., 2001. Greenhouse gas emissions during cattle feedlot manure composting. J. Environ. Qual. 30, 376-386.

Hutchinson, G.L., Mosier, A.R., 1981. Improved soil cover method for field measurement of nitrous-oxide fluxes. Soil Sci. Soc. Am. J. 45, 311-316.

IPCC, 2007. Climate Change 2007: The physical Science Basis. Contibution of Working Group I to the Fourth Assessment report of the Intergoverenmental Pannel on Climate Change. Cambridge University Press, Cambridge, UK.

Laidlaw, W.S., Arndt, S.K., Huynh, T.T., Gregory, D., Baker, A.J.M., 2012. Phytoextraction of heavy metals by willows growing in biosolids under field conditions. J. Environ. Qual. 41, 134143.

Livesley, S.J., Kiese, R., Graham, J., Weston, C.J., Butterbach-Bahl, K., Arndt, S.K., 2008. Trace gas flux and the influence of short-term soil water and temperature dynamics in Australian sheep grazed pastures of differing productivity. Plant Soil 309, 89-103.

Livesley, S.J., Kiese, R., Miehle, P., Weston, C.J., Butterbach-Bahl, K., Arndt, S.K., 2009. Soilatmosphere exchange of greenhouse gases in a Eucalyptus marginata woodland, a clover-grass pasture, and Pinus radiata and Eucalyptus globulus plantations. Glob. Change Biol. 15, 425-440.

Matson, P.A., Harriss, R.C., 1995. Biogenic trace gases: Measuring emissions from soil and water. Blackwell Science Ltd, London, UK. p. 38.

Melbourne Water, 2010. Implementation of a research and development project for envergy, nutrient, metal, fuel or chemical extration, geotecnical reuse, building material extender, decontamination, stabilisation, or other conversion leading to "Beneficial Use" of biosolids. Melbourne Water Corporation, Melbourne.

Minato, K., Kouda, Y., Yamakawa, M., Hara, S., Tamura, T., Osada, T., 2013. Determination of GHG and ammonia emissions from stored dairy cattle slurry by using a floating dynamic chamber. Anim. Sci. J. 84, 165-177. 
Murphy, D.V., Recous, S., Stockdale, E.A., Fillery, I.R.P., Jensen, L.S., Hatch, D.J., Goulding, K.W.T., 2003. Gross nitrogen fluxes in soil: Theory, measurement and application of N-15 pool dilution techniques. Adv. Agron. 79, 69-118.

Peigne, J., Girardin, P., 2004. Environmental impacts of farm-scale composting practices. Water Air Soil Pollut. 153, 45-68.

Pritchard, D.L., Penney, N., McLaughlin, M.J., Rigby, H., Schwarz, K., 2010. Land application of sewage sludge (biosolids) in Australia: risks to the environment and food crops. Water Sci. Technol. 62, 48-57.

Raich, J.W., Schlesinger, W.H., 1992. The global carbon-dioxide flux in soil respiration and its relationship to vegetation and climate. Tellus Ser. B-Chem. Phys. Meteorol. 44, 81-99.

Roy, M.M., Dutta, A., Corscadden, K., Havard, P., Dickie, L., 2011. Review of biosolids management options and co-incineration of a biosolid-derived fuel. Waste Manage. 31, 22282235 .

Thangarajan, R., Bolan, N.S., Tian, G.L., Naidu, R., Kunhikrishnan, A., 2013. Role of organic amendment application on greenhouse gas emission from soil. Sci. Total Environ. 465, 72-96.

Wang, H.L., Brown, S.L., Magesan, G.N., Slade, A.H., Quintern, M., Clinton, P.W., Payn, T.W., 2008. Technological options for the management of biosolids. Environ. Sci. Pollut. Res. 15, 308317.

Weih, M., Nordh, N.E., 2002. Characterising willows for biomass and phytoremediation: growth, nitrogen and water use of 14 willow clones under different irrigation and fertilisation regimes. Biomass Bioenerg. 23, 397-413.

Zhang, H., Guan, D.S., Song, M.W., 2012. Biomass and carbon storage of Eucalyptus and Acacia plantations in the Pearl River Delta, South China. For. Ecol. Manage. 277, 90-97. 